(2) Open Access Full Text Article

\title{
Reasons for delaying or engaging in early sexual initiation among adolescents in Nigeria
}

\author{
Augustine Ankomah' \\ Fatima Mamman-Daura ${ }^{2}$ \\ Godpower Omoregie! \\ Jennifer Anyanti' \\ 'Society for Family Health, Abuja; \\ 2Pathfinder International/Nigeria, \\ Kaduna Field Office, Kaduna, Nigeria
}

This article was published in the following Dove Press journal:

Adolescent Health, Medicine and Therapeutics

8 September 2011

Number of times this article has been viewed
Background: Annually, over 1 million births in Nigeria are to teenage mothers. Many of these pregnancies are unwanted and these mothers are also exposed to the risk of human immunodeficiency virus (HIV) infection. Sexual abstinence is a critical preventative health strategy. Several quantitative studies in Nigeria have identified the correlates and determinants of early sex, yet few have explored in depth the underlying reasons for early sex. This paper explores both the key factors that motivate some unmarried young people to engage in early sex and reasons why some delay.

Methods: This qualitative study was based on data from 30 focus group discussions held with unmarried 14- to 19-year-olds in four geographically and culturally dispersed Nigerian states. Focus groups were stratified by sexual experience to capture variations among different subgroups.

Results: Several reasons for early premarital sex were identified. The "push" factors included situations where parents exposed young female adolescents to street trading. "Pull" factors, particularly for males, included the pervasive viewing of locally produced movies, peer pressure and, for females, transactional sex (where adolescent girls exchange sex for gifts, cash, or other favors). Also noted were overtly coercive factors, including rape. There were also myths and misconceptions that "justified" early sexual initiation. Reasons cited for delay included religious injunction against premarital sex; disease prevention (especially HIV/acquired immunodeficiency syndrome); fear of pregnancy, and linked to this, the fear of dropping out of school; and, for females, the fear of bringing shame to the family, which could lead to their inability to get a "good" husband in the future.

Conclusion: The differences observed between sexually active and abstinent adolescents were that the latter were more confident, had greater determination, and, most important, deployed refusal skills to delay first sex. Health promoters need to focus attention on educating adolescents in the skills needed to delay sexual debut.

Keywords: abstinence, sexual initiation, adolescents, qualitative, focus group discussions, Nigeria

\section{Introduction}

In Nigeria, over 35 million people are aged 10-19 years, making sexual abstinence among adolescents a critical preventative strategy against human immunodeficiency virus (HIV) infection in a country where $3 \%$ of 15 - to 19 -year-olds are HIV positive. ${ }^{1}$ From an international perspective, any study on the sexual health of Nigerian adolescents is of significance to sub-Saharan Africa, as a third of African adolescents live in Nigeria and the country's birth rate among adolescents is one of the highest in the world. ${ }^{2}$ About 1 million births per year in Nigeria are to teenage mothers, and
Correspondence: Augustine Ankomah Society for Family Health, 8 Port Harcourt Crescent, Garki, Area II, PMB 5I I6, Wuse Abuja, Nigeria Tel +2348082338720

Fax +23494618823

Email aankomah@sfhnigeria.org 
abortion complications are responsible for $72 \%$ of all deaths among teenagers aged under 19 years. ${ }^{3}$ In 2008, 23\% of women aged 15-19 years were already mothers or were pregnant with their first child. In the North West Zone (one of Nigeria's six geopolitical zones), teenage childbearing is as high as $45 \%{ }^{4}$

In $2008,20 \%$ of women in Nigeria were sexually active by age 15 , and the median age for first sex stood at 17.7 years for women and 20.6 years for men. ${ }^{4}$ In rural areas, sexual debut is even earlier. Early sexual initiation lengthens the period of exposure to unwanted pregnancies, HIV, and other sexually transmitted infections and youth who begin sexual activity earlier appear more likely to have sex with highrisk partners or multiple partners and are less likely to use condoms. ${ }^{5}$ In Nigeria, previous studies have validated the observation that sexual activity among unmarried adolescents and young adults is on the rise. ${ }^{4,6-9}$

Several quantitative studies have identified correlates and determinants of early sex. ${ }^{6-8,10-14}$ In addition, there have been qualitative, including ethnographic and anthropological, studies that have explored the social context of premarital sex, courtship, and extramarital sex. For example, Smith ${ }^{15,16}$ and Izugbara $^{17,18}$ have examined the social context of premarital sexual relationships among the Igbo of southeastern Nigeria. Earlier, other studies discussed the influences of adolescent sexuality, ${ }^{19}$ and adolescent perception of sexuality and sexually transmitted infections in Benin City. ${ }^{20}$ The ethnography of gender, economics, and the power dynamics of sexuality in southwestern Nigeria has also been studied. ${ }^{21}$ First, most of the reported qualitative studies offer detailed anthropological and ethnographic discussions of sexuality. While some of the studies discuss reasons for premarital sex, including premarital multiple partnering, ${ }^{15-18,20,21}$ none concentrates specifically on reasons for first sex or for delay in sexual initiation. Secondly, nearly all the qualitative studies are limited to single cities, towns, or ethnic groups. ${ }^{15-18,20,21}$ This study compliments the existing literature and deepens the understanding of early sexual initiation by using qualitative data to explore the issue in several cities and across ethnic groups. While there is some information on reasons for premarital sex and premarital multiple partnering, at the moment there is a dearth of qualitative information specifically on reasons for and experiences surrounding first sex. This information is needed to inform policy makers and HIV prevention programmers who promote delay of first sex as an additional HIV prevention strategy, given that less than $20 \%$ of Nigerian adolescents used a condom at first sex. ${ }^{13}$ The main objective of this paper, therefore, is to explore the key factors that motivate some young people to engage in early sexual initiation and the reasons why others delay first sex.

\section{Methods and materials}

This was a qualitative study with data derived from 30 focus group discussions (FGDs) held with sexually active and abstinent single adolescent males and females aged 14-19 years living with parents or guardians. To ensure the ethnic and religious diversity of participants, the study was conducted in four geographically and culturally distinct locations in four Nigerian states: Lagos and Oyo in the west, Kano in the north, and Enugu in the east. The FGDs were stratified by sexual experience and age $(14-16 ; 17-19)$ to capture variations among different subgroups and to allow for homogeneity. Details of the composition of the focus groups and the number of participants are shown in Table 1. Fourteen focus groups were conducted among sexually experienced (seven for males and seven for females) and 16 groups among sexually inexperienced (seven for females and nine for males).

\section{Sampling and recruitment of study participants}

The four cities were deliberately selected to reflect the main ethnic and geographical divisions of Nigeria. Kano in the north is predominantly Muslim and inhabited by the Hausa tribe; Ibadan in the west is the largest city of the Yorubas, as

Table I Composition of focus group discussions

\begin{tabular}{|c|c|c|c|c|c|c|c|c|c|}
\hline \multirow[b]{3}{*}{ Age group (years) } & \multicolumn{4}{|l|}{ Male } & \multicolumn{4}{|c|}{ Female } & \multirow[t]{3}{*}{ Total } \\
\hline & \multicolumn{2}{|c|}{ Nonabstinent } & \multicolumn{2}{|c|}{ Abstinent } & \multicolumn{2}{|c|}{ Nonabstinent } & \multicolumn{2}{|c|}{ Abstinent } & \\
\hline & $14-16$ & $17-19$ & $14-16$ & $17-19$ & $14-16$ & $17-19$ & $14-16$ & $16-19$ & \\
\hline Lagos & I (8) & $I(10)$ & $I(10)$ & I (9) & I (8) & I (9) & $I(10)$ & I (8) & $8(72)$ \\
\hline Ibadan & - & I (9) & - & I (9) & - & I (9) & - & I (8) & $4(35)$ \\
\hline Enugu & I (8) & I (I0) & I (9) & I (9) & I (9) & I (I0) & $\mathrm{I}(10)$ & I (8) & $8(73)$ \\
\hline Kano & - & $2(15)$ & $2(20)$ & $2(19)$ & I (8) & I (9) & I (9) & I (9) & $10(89)$ \\
\hline Total & $2(16)$ & $5(44)$ & $4(39)$ & $5(46)$ & $3(25)$ & $4(37)$ & $3(29)$ & $4(33)$ & $30(269)$ \\
\hline
\end{tabular}

Note: First number = number of FGDs; second number in parentheses = number of participants.

Abbreviation: FGDs, focus group discussions. 
Enugu is to the Igbos of eastern Nigeria. Lagos was included because it is Nigeria's largest commercial city and the most multi-ethnic. Three of the four cities were stratified into two main strata: the main city and the periurban (commutable formal and informal settlements on the fringes of the main city), while Kano was stratified into the "old city" and "the rest of Kano." For each of the constituent divisions, the sampling frame consisted of the list of all wards, the lowest geopolitical unit. At the next stage, wards were selected to reflect socioeconomic and other specific variations. Two wards were selected from each of the two divisions in Ibadan, Lagos, and Enugu (a total of four wards per city), while five wards were selected in Kano (one in Old Kano and four in the rest of Kano). Two focus groups were held per ward in each city (one male and one female), except in Ibadan where only one was held per ward.

Given the age of the participants, permission from parents and guardians was sought and obtained to interview the participants. The voluntary nature of participation was stressed to both participants and parents.

Based on the local knowledge of some of the authors and the FGD moderators, the appropriate community leaders were contacted and permission sought to undertake the study. After clearance and approval was granted, the research team member with appropriate knowledge of the community identified and recruited "ward mobilizers" (one male and one female) for each ward with the help of the FGD moderator (a local but not from the immediate community). With their substantial local knowledge of the community, and based on the briefing of the research team, the ward mobilizers identified houses where potential study participants lived. Home visits were made by the ward mobilizers and the appropriate member of the research team. The general objective of the study was explained to parents. Informed consent was obtained from both parents and each potential participant.

Before the FGDs took place, a follow-up visit was made by the appropriate FGD moderator. During this second visit, the moderator spoke exclusively with the potential participant in confidence, built some rapport, and asked the adolescent a screening question: whether they had ever had sex. This was crucial, since separate FGDs were held for abstainers and nonabstainers. The pre-FGD visit also served another purpose; it was expected, as shown in northern Nigeria, that the adolescents would speak freely at the FGDs if they had met the moderators prior to the FGD. ${ }^{22}$ (It should be noted that, to ensure confidentiality, the ward mobilizer, who was often known in community, had by now completed their tasks and were not privy to the information about whether the adolescents were sexually experienced or inexperienced.)

To include as many households as possible, only one participant per home was chosen. Based on the response to the screening question, the date and venue for the FGDs were agreed.

\section{The FGDs}

Axelrod's ${ }^{25}$ suggestion that, given the sensitive nature of the dialogue, discussion groups should be divided into male and female was followed: male moderators led discussions with males and female moderators with females.

Each focus group membership ranged from eight to ten participants to make for varied, interesting, and sustained discussions. ${ }^{23,24}$ The FGDs were held in venues convenient for participants and these included church halls, open market squares, verandas, and schools.

\section{Structure of FGDs}

All discussions were held in either the appropriate local language or in Pidgin English. Each discussion lasted for about 90 minutes after which refreshments were provided to participants. Participants were served with snacks, but, to remove any potential bias, no financial or other incentives were offered to participants, although travel expenses were reimbursed.

In each focus group a young moderator was assisted by a note taker who captured, among other things, nonverbal responses, cues, and other interactions. Moderators and note takers were trained by the authors on all aspect of FGD moderation. The FGD guide was pretested as part of the training. FGDs were tape recorded with the consent of participants.

\section{Topics}

The FGD facilitator led discussion on topics related to abstinence from three different angles: personal, dyadic, and societal. Individual level topics included, among others, perception of and knowledge about abstinence, effects of engaging in early sexual intercourse, self-efficacy to abstain, and experiences of first sex (defined as heterosexual penile-vaginal only). The dyadic issues explored included the nature and extent of pressure from friends, peers, and romantic partners to engage in sexual activity; the difficulties and challenges of remaining abstinent; and circumstances surrounding the first sexual experience. Some community factors were also discussed: community perception about virginity; social support to delay sex; the roles of culture, religion; and misconceptions about abstinence. 
After each discussion, participants were encouraged to ask questions and many misconceptions about early sex and abstinence were addressed. Many of the post-FGD questions and issues were anticipated in advance and this formed part of the training of moderators. It is important to mention that the post-FGD interactions were not recorded and were not included in the analysis.

\section{Analysis}

Recorded FGD sessions were fully transcribed and translated verbatim into English. The transcript of each group was read by at least three of the authors. Coding was done manually. The codes were made up of keywords and phrases developed from the data. The codes were then "grouped together under higher order headings." ${ }^{26}$ Consequently, on a higher logical level of abstraction, codes, subcategories, categories, and themes were created.

Four key themes were identified regarding sex: restraining factors, push factors, pull factors, and coercive factors. Push factors were defined as any "enabling" factors that were internal, ie, that originated in the adolescent or the immediate family. Pull factors offered attractions to engage in first sex; these were from an external source and included community as well as friendship and peer-related issues. Coercive factors were considered to be outside the control of the adolescent and bordered on illegal sexual violation. Finally, restraining factors were those that motivated adolescents to delay early sexual initiation.

Both manifest and latent content analyses were employed in the interpretation of data. Qualitative analysis may focus on manifest or latent content. ${ }^{27}$ Manifest analysis describes the visible and the obvious while latent content analysis involves an interpretation of the underlying and inferred meaning of texts. ${ }^{27,28}$ Latent analysis allows for in-depth interpretation and systematic and thorough evaluation to assess the presence or absence of particular idea or theory. ${ }^{27,28}$ The research team met on various occasions to discuss the coding, analysis, and interpretations of the data and addressed discrepancies that required clarity. Representative quotes that best illustrated the four themes outlined previously were agreed upon by the authors and selected, but in some instances contrasting minority opinions were also highlighted.

\section{Results and discussion}

On the whole, discussions about sexual matters were frank and candid for both sexes, although a few sexually inexperienced females were initially reticent. One key methodological finding was that gaining access to participants and bringing them together to discuss sensitive sexual matters was not as difficult as initially thought.

\section{Characteristics of participants}

Participants in the study were single males and females aged 14-19 years. The total number of FGDs in each city and their compositions (age group, group size, and sexual experience of participants) are shown in Table 1. A total of 269 young persons, 145 males and 124 females, participated. In terms of sexual experience, 122 (60 males, 62 females) had engaged in sex while 147 ( 85 males, 62 females) had never had sex. Only a few participants were recruited in Ibadan because of its cultural affinity to Lagos. The tribal origin of participants reflected the location of the FGD. Nearly all participants in Kano were Hausas, in Ibadan were Yorubas, and in Enugu were Igbos. In Lagos, however, the participants were mixed. Although the majority were Yorubas, there was a fair representation of participants from other tribes, including Igbo and other minority tribes from the South South Zone and the Middle Belt. All participants from Kano were Muslim, just as all those from Lagos and Enugu said they were Christian. In Ibadan, there was a mixture of Christians and Muslims.

In terms of educational background, all female participants in Enugu were secondary school students while the males included students and a few school dropouts. In Ibadan, all male participants were secondary school students while a few of the females only had primary school education. In Lagos, both male and female groups included participants with primary education only, those with some secondary education, and those who were currently secondary school students. In Kano, participants included those in secondary school, those who had only basic Qur'anic education, and a few who had never been to school at all.

To explore the reasons for early sexual initiation, the results are presented under four main thematic headings: the pull, push, coercive, and restraining factors.

\section{Pull factors}

\section{The role of Nigeria's locally produced movies}

Locally produced movies as well as foreign films were identified, particularly in Lagos, as a key catalyst for engagement in first sex, particularly for males. Nigeria's film industry produces hundreds of movies every year with plots depicting scenes often woven around love, sex, money, and deception among lovers. In a few cases, young people had access to "X-rated" films that could be rented from 
local shops. In the Nigerian context, any film or home video showing some form of nudity is called "blue film." Although not anywhere near being pornographic in the Western sense, they nevertheless contain scenes of sex and nudity that can act as a trigger for early sex. This was true particularly for the males. Some scripted their first sexual experiences:

I got involved the first time through watching film ... I was at home watching film and they were doing it [having sex] in the film. I was at home alone and just then this girl entered so we did it [had sex]. (Male)

What led me into having my first sexual experience was that one day we went to rent a blue film and put it into the machine, as we were watching it we were terribly moved including that girl. Before we finished watching it we attempted to practice it and we had sex. (Male)

The first day I had it [first sex], I was at home with my girlfriend and my brother was not around and my friend went out to go and borrow that film ... the blue film. And when me and the girl saw the way they were doing it [having sex]; and later we did the thing together. ... I was 16 ... She was also 16. (Male)

My first experience; it was with a girl in my house, then there was a film my friend brought, blue film. We watched the film together I sat beside her she looked at my face and I looked at her face. She laughed and I asked whether she liked the film we were watching; and she said she liked it and I asked her to let us "practicalize" what we have seen and we did it. ... I was 14 ... and she was 14 years too. (Male)

Surprisingly, the role played by locally produced and foreign movies in early sexual initiation in Nigeria is hardly discussed. The films are easily available and there are places spread throughout poor neighborhoods in urban areas and in rural localities where the films can be viewed.

\section{Myths and misconceptions about abstinence}

There were several misconceptions about adolescence and first sex. Of all the myths mentioned, only one, reported by a male from Enugu, was in favour of delayed sexual debut: that early sex for boys will cause the penis to be "locked up" inside the woman: "If you do it underage, maybe as you are doing it, your manhood will get stuck in the woman's something [vagina]."

All other myths and misconceptions about first sex and abstinence provided some justification for early sex and such views were strongly held by both males and females. It was believed that failure to have sex early would make one develop pimples, grow fat, become infertile in the future, or could even result in death. It did not appear that the myths on their own motivated adolescents to engage in early sex. However, when they are combined with other reasons, it can push both males and females into early sex, or at least offer some justification. One thing was clear - nearly all the misconceptions were in support of early sexual debut by portraying the "horrible things" that would happen if sexual initiation is delayed:

If you stay that way [if you abstain], you will develop pimples on your face; no man will look at you anymore. (Female)

As a guy, if you don't have sex, you will start growing fat and develop pimples, boils, and sickness. (Male)

I even heard that if you don't have sex when you reach a certain stage in your life you may even die of [accumulated] sperm. (Male)

Some believed that being a virgin would make penetration difficult during marriage when you wanted to have intercourse with your husband. Another key misconception was that delaying sex could lead to infertility in the future:

Some say that if you don't have sex before you marry your husband will suffer because he can't succeed in making love to you [unable to penetrate] and that having children will be a problem. I have also seen so many people who marry as virgins ... some have been married for like 5 years but they don't have children yet. (Female)

Those who had had sex narrated myths and misconceptions favoring early sexual debut, while those with no sexual experience told those in favor of late sexual debut.

\section{The role of friends and peers}

A key pull factor mentioned by nearly all participants was the prominent role of friends in sexual initiation. Friends played a major role in the experiences of first sexual encounters, especially among male youth.

Young men point to friends as the main motivation for them to engage in first sex. Pressure to conform was mentioned as very critical. It was observed that young men, more than women, were likely to be influenced by their peers to engage in early sex. The pressure could range from subtle name calling to physical harassment.

Friends! Friends! If you don't have that sex now they will say that you are not current, thereby they will say you are not sharp; they will call you a homosexual. (Male) 
Name calling was also mentioned among females, although much less frequently.

It's the friends, even if you decide to abstain, friends will abuse you calling you names like - "mumu [a fool], virgin Maria, Jesus sister, Angel" - saying that "you should stay there and develop pimples on your face, no man will look at you anymore." (Female)

It happened that one girl asked me to come and keep her company, she is bigger [in size] than me. I knew a lot about sex before then but my friends thought I was lying when I told them that I have never had sex ... We did not do it [have sex] that day. When I left I went to some of my friends and told them what happened. They rained insults on me and nearly beat me up. That I was not a man enough, how should I allow a girl like that to go free. They encouraged me so the next day she invited me again. I was prepared, so I did it [had sex] with her. (Male)

For males, it was also found that one area of "support" and encouragement given by nonabstinent peers to abstinent friends was, among other things, offering advice about language and appropriate tricks and skills to use to seduce girls:

We live together on the same street, my friends taught me how to go and meet her. I now told her I wanted to have sex with her; she told me she was a virgin. I went back and told my friends and they told me that girls use to say that so I should go back and try again. I went back another day she came to my house and we did it [had sex]. (Male)

Sexually experienced peers also set up trysting spots and created enabling environments for the abstinent peers:

My first time ... my friends approached the girl ... It was Valentine's day. ... Then they all came to my house with the girl. Then after some time they all left the room and left me and the girl alone together ... and we did it [had sex] together.

... I was 17 years and she was 16 years. (Male)

Some of the young women had sex for the first time because they felt that giving in to sex was the best way of expressing love for their partner. To some of the participants there could be no love without sex, and the fear of losing a boy- or girlfriend acted as a strong pull factor:

If a lady likes a man, anything he asks her, she will do it ... she will have no resistance, because she loves him ...

The reason is the fear of losing partner, so they accept. (Female)
In several other studies in Africa, ${ }^{29-31}$ the perception of whether peers had initiated their first sexual encounter, perception of peer attitudes toward sex, knowing a peer who has had sex, or having a number of friends who were already having sex were strong predicators of sexual activity. Young men point to friends as the main motivation to engage in first sex. In the present study it was observed that young men, more than women, are likely to be influenced by their peers to engage in early sex.

\section{The media}

The media was said to have both negative and positive influence. Exposure to television has been found in quantitative studies as a key correlate to onset of early sex, ${ }^{14}$ and this was confirmed in the present study. In the FGDs, participants mentioned that while the media, in particular television, can educate young people about the need to abstain or delay sex, they also show "how to perform, how to demonstrate the thing."

They teach us what is good and what is bad. Sometimes, they might just show a naked boy and a naked girl then you will feel like doing it. You'll feel like being in their midst. However there are some good programs also you will watch that will help you so much. (Female)

Some young men also claimed that the natural drive and "uncontrollable sexual urge" is often made difficult to control or compounded by what is shown on television, ie, that some TV programs go "too far":

What I'm saying is that even if one should try to abstain, just you watching the TV program you cannot abstain. (Male)

\section{Push factors}

\section{The role of parents}

Parents were considered as the primary shapers of their children's behavior, including sexual behavior. They have great influence over whether their wards abstain. Youth showed awareness of the effect their parents have on their sexual behavior. Evidence from the FGDs suggested that participants felt that parents could have either negative or positive influence on the sexual activity of their children. On one hand, children of "good" parents have good home training and would grow up to be youth who abstain until marriage, while, on the other hand, children (especially females) of "bad" parents stand a higher chance of being pushed consciously or unconsciously by their mothers into early sexual initiation. 
For some of us our parents teach us not to join bad friends that practice sex. (Female)

Those that are well trained by their parents; the father always pays attention to what his daughter is doing even when a man calls her for sex, she will know the father is strict so she will refuse. (Female)

And those that their parents always scold them when they go wrong often say no to sex. (Male)

Where parents did not appear to care or take interest in what adolescents did, sexual initiation was often earlier. Such a home environment went a long way toward pushing young persons to have early sex by breaking any resistance they may have.

It's very difficult; because ... [if you are a] person that come[s] from [a] bad home you are watching bad films from there, you start having sex. (Male)

At times it is the fault of our parents who expose us to "zance" [regular talking/chatting with prospective suitors] at a very early age. (Female)

One area, mentioned particularly by females, was how parents, mainly as a result of poverty, exposed female adolescents to early sex by asking them to engage in street trading or hawking goods in the neighborhood. Some mentioned that a "bad" mother will punish her daughter if she fails to make enough sales. To avoid parental wrath, some men take advantage of them by buying in bulk "everything we sell every day" in exchange for sex. A participant mentioned how she lost her virginity as a result of this parentally induced transactional sex:

My mother sends me to sell - to contribute, so they can get money. They will give those things to go and sell ... if you sell and the money is not complete [ie, if she is not able to sell all the items], there is always trouble when you go home. So I had do it [have sex], to get all the money to send home. ... The man will buy everything I am selling. (Female)

This risky situation was exacerbated by the fact that many parents were unable or unwilling to tell their children directly to abstain from sex. Parents were accused, by some participants, of not being straightforward when giving advice, which ended up confusing them:

Our parents they don't do or say something straightforward

... they will say it instead of them to advise that we should not have sex, you can get HIV, they will not do it they will be saying it somehow [indirectly]. (Female)

\section{Poverty and transactional sex}

One major enticement to engage in early sex, referred to in the preceding section, is the perceived or real rewards, both financial and material, that may be gained from trading first and subsequent sexual interactions for money or gifts. Many of the young women outlined some of the items they were promised that motivated them to have sex. Rewards included cash, gifts (especially mobile phones), and, in educational establishments, favors relating to admission and examinations.

You will be looking for somebody that will buy you clothes and when you sleep with them, they buy you different types of clothes. (Female)

Most times if you are from a poor family and a boy promises to give you something [financial rewards] you will decide to do it so that you will get money to solve your problems. (Female)

Some of the female participants saw sex as a means of "survival," so abstinence was not an option for them. Transactional sex is pervasive in West Africa in both premarital and extramarital sex. ${ }^{32,33}$

\section{"Uncontrollable" natural sexual urge}

Many of the males, especially those who had already had sex, emphasized the involuntary aspect of human sexuality and their inability to abstain, which they claimed was not helped by what they watched on television and the way adolescent females often dressed.

Because our hearts have already been conditioned to have sex, if not we will not be happy. It is an emotional feeling you cannot stay away from it. Because if you've have never had the sex you won't feel comfortable. (Male)

\section{Coercive factors}

There was evidence that in some instances first sex was the result of sexual violence including rape and other forms of coercion. Male teachers were singled out as the worst offenders. The female participants, supported by some males, narrated several cases of sexual harassment and intimidation against adolescent girls who do respond favorably to sexual advances from their teachers. Cases of rape were reported.

Some male teachers drag you to the staff room and start telling you how fine and beautiful you are. They can even beat the girl [corporal punishment] if she refuses to have sex with them. (Female) 
I have already seen that kind of a teacher, they beat that girl ... At last [in the long run] what he is looking for is sex. (Male)

It happened in my village. That girl fetches water for the teacher. The girl also cooks for him sometimes. All this was happening because the teacher was close to [the girl's] parents. One particular day it was late in the evening, the man asked her to bring to his house homework exercise books for him. When she brought those books into his room the man held her. He raped her. (Female)

For vulnerable young girls in positions of very little power, such as those working as domestic maids, it was reported that sexual debut was often the result of rape or some other sort of coercion.

The role of some female teachers in educating females adolescents to remain abstinent was reported by some female FGD participants.

Like my teacher whenever she advises that we should stay away from sex. Sometimes she will use the garage boys and other school dropouts on the street as an example for us. She said it's to help our future and against unwanted pregnancy, they encourage. (Female)

\section{Restraining factors: why do some adolescents delay first sex?}

Though a myriad of reasons were given by young persons who have not had sex as reasons why some youth stay away from sex, five interrelated reasons were most commonly given. These were: religious injunction against premarital sex, disease prevention (especially HIV/AIDS), the fear of pregnancy and, alongside this, the fear of dropping out of school, and the fear of bringing shame to the family, which would lead to the inability to get a "good" husband in future. But participants pointed out that the key to remaining abstinent was to "be focused and determined." Both male and female abstinent adolescents emphasized that anyone who wanted to abstain must have a clear reason why they were abstaining, and they must have something in mind they were pursuing. A male participant from Ibadan confirmed: "The reason I agreed to stay away ... [it] means I have something in mind to do; I am a student. I have had it in mind that when I finish [secondary school] then I will start having it [sex].”

As for me I keep away from it [sex] because ... if I go into it I might be impregnated or contract any disease. I know what I want for my future that's why I shy away from it. (Female)
Among some of the participants, the possibility of the man refusing to accept responsibility for pregnancy served as major restraint. Another reason for abstaining given by females was so that their reputations could be kept intact for good marriage. Maintaining a good family name and image was considered critical for getting a good husband. Some, particularly those who were Muslim, considered it shameful for the family to have a pregnancy out of wedlock. A male participant in Kano stated "I personally stay away from sex in order to avoid shame to my parents." From the religious angle, both Muslim and Christian youths mentioned that their religion forbids pre- and extramarital sex, which was the primary reason religious participants gave for abstinence.

It's bad because the Bible says that we should live in holiness, you don't have anything to do with sex before marriage. (Female)

A related reason was fear of abortion arising from premarital pregnancy and the possibility of infertility in the future arising from unsafe abortion. While many were only afraid of unwanted pregnancies, a few were worried about losing their virginity and its cultural implications, given the perceived cultural importance of virginity until marriage. For those that believed in this, that was the very reason for abstinence.

Some family they believe that it's good to marry a virgin. What they do is that before they marry they will check if their bride is virgin or whether she had spoilt her life. (Female)

The dream of entering a man's home as a virgin was a romantic dream of a few participants and an expectation from some mothers.

My mum does tell me that there is pride in being a virgin

... [the future husband] will praise; buying you things. He will say you are a good girl before he got married to you ... (Female)

Another female participant from Kano stated "people abstain to get good husbands."

There was an obvious skewed gender relationship between being a virgin and getting a good spouse - only the abstaining females thought being a virgin would get them a good husband; no male felt that abstaining would get them a good wife. It was also made evident that a man is not supposed to be a virgin at marriage. 


\section{Skills needed to remain abstinent}

It was observed that, apart from the general reasons mentioned previously, participants who were abstaining had some practical skills and strategies they employed to remain abstinent. Those abstaining appeared to be more confident, had greater determination to remain so, and had appropriate skills they employed when under peer pressure.

Some girls mentioned that a key strategy was to avoid visiting boys since the boys "cannot come and meet you and have sex with you in your father's house." A male participant mentioned that the people who can abstain were "only those who know what [benefit] can come out of saying no."

Even in the church it all depends on determination. ... I can stand on my right that I won't do it because my friends are doing it ... You avoid sex by watching the kind of friends you move with. Some boys and girls are wayward. If you move with such, you will become like them. So watch the kind of friends you keep so that will not be deceived. (Female)

Many participants, particularly females, emphasized that the need to be determined and focused should not be left "within you," pointing out that if "it's dormant it won't work." To succeed, you should let your friends and peers know that "you're determined" so that the boys will "leave you alone." They mentioned the need to let boys know that you are not interested in sex and you like it that way. They advised not giving the boys any chance to make advances:

We are now in a mixed school, boys and girls. There are some of my classmates that some of the boys will talk to and the girls will be laughing. You know boys in my class are fond of that, if you don't want anything to do with them, like me, you should tell them plainly. When they touch you and you start laughing you encourage them. But if you insult the boys when they touch you, they won't come close to you again. (Female)

Some even showed some rudimentary skills (learned through health education training sessions) in anticipating risky interactions, particularly with "older men," by thinking and "knowing what is in their mind." Some saw the need to understand the potential risky situation by predicting the stages of sexual scripting:

During a time we went for a program they told us to look at that person straight in the face as to detect what he's really up to. You will know his intentions by looking at his face ... and then you can decide what to do next. (Female)
Our findings are supported by several other studies in Africa, ${ }^{29,34,35}$ which suggest that higher levels of selfesteem are a key determinant in delaying first sexual intercourse.

Although this study provides data in understanding the reasons for early sexual initiation and why some adolescents continue to remain abstinent, as a qualitative study with potential biases resulting from selection issues, the results of the study are not representative and therefore not generalizable to all 14-19-year-olds in Nigeria. Furthermore, the qualitative data could be subject to multiple interpretations.

\section{Conclusion}

For youth, abstinence is feasible but difficult to practice.

Saying no to sex can be very difficult, especially if the home environment and/or peers are less supportive. The differences observed in sexually active and inactive youth were that those abstaining appeared to be more confident, had greater determination, and were less likely to succumb to peer pressure. This strength may be internal, or gained from support in their environment.

Any intervention promoting abstinence may need to take into account the real-life situations and the pressures abstinent adolescents face and offer them skills on how to address such community-specific challenges if they are to succeed in delaying sexual initiation. It is important to mention that to have successful programs, there should be more than single messages emphasizing the need to delay. Programs that address a broad range of issues are needed. They may include programs on enhancing self-esteem, the development of "refusal skills," and follow-up skills that will help young persons make and follow through on good decisions relating to their futures.

This study highlighted the fact that for some girls their first sex was rape; this was especially true for housemaids or other domestic home help. There is the need for the issue of sexual violence perpetrated against these vulnerable groups to be addressed through health campaigns.

\section{Acknowledgment}

The study upon which this paper was based was supported by the British Department for International Development, the US Agency for International Development and the Nigeria Federal Ministry of Health.

\section{Disclosure}

The authors declare no conflicts of interest in relation to this paper. 


\section{References}

1. Department of Public Health, National AIDS/STI Control Programme, Federal Ministry of Health [Nigeria]. Technical Report: The 2010 National HIV/Syphilis Sero-prevalence Sentinel Survey among Pregnant Women Attending Antenatal Clinics in Nigeria. Abuja: Federal Ministry of Health, 2011. Available from: http://www.nigeria-aids. org/documents/2010_National\%20HIV\%20Sero\%20Prevalence $\% 20$ Sentinel\%20Survey.pdf. Accessed July 30, 2011.

2. Slap GB, Lot L, Huang B, Daniyam CA, Zink TM, Succop PA. Sexual behaviour of adolescents in Nigeria: cross sectional survey of secondary school students. BMJ. 2003;326(7379):15.

3. National Population Commission (NPC) [Nigeria] and ORC Macro. 2003 Nigeria Demographic and Health Survey. Calverton, MD: NPC and ORC Macro, 2004. Available from: http://www.measuredhs. com/pubs/pub_details.cfm?ID=454\&ctry_id=30\&SrchTp=available. Accessed July 30, 2011.

4. NPC [Nigeria] and ORC Macro. 2008 Nigeria Demographic and Health Survey 2008. Calverton, MD: NPC and ORC Macro; 2009. Available from: http://www.measuredhs.com/pubs/pub_details. cfm?ID $=970 \&$ ctry_id $=30 \&$ SrchTp=available. Accessed July 30, 2011.

5. World Health Organization (WHO). The World Health Report 2004: Changing History. Geneva: WHO; 2004. Available from: www.who. int/whr/2004/en/report04_en.pdf. Accessed July 30, 2011.

6. Orosanye AU, Odaise GI. Attitudes toward abortion and contraception among Nigerian secondary school girls. Int J Gynaecol Obstet. 1983;21(5): 423-426.

7. Nichols D, Ladipo OA, Paxman JM, Otolorin EO. Sexual behaviour, contraceptive practice, and reproductive health among Nigerian adolescents. Stud Fam Plann. 1986;17(2):100-106.

8. Ezimokhai M, Ajabor LN, Jackson M, Izilien M. Response of unmarried adolescents to contraceptive advice and service in Nigeria. Int J Gynecol Obstet. 1981;19(6):481-486.

9. Adetoro OO, Babarinsa AB, Sotiloye OS. Socio-cultural factors in adolescent septic illicit abortions in Ilorin, Nigeria. Afr J Med Med Sci. 1991;20(2):149-153.

10. Isiugo-Abanihe UC. The correlates of premarital sexuality in Nigeria. Afr J Psychol Study Soc Issues. 1994;1(2):257-276.

11. Isiugo-Abanihe UC, Oyediran KA. Household socioeconomic status and sexual behaviour among Nigerian female youth. African Population Studies. 2004;19(1):81-98.

12. Agha S, Van Rossen R, Ankomah A. Community Level Influences on Early Sexual Initiation in Nigeria. Measure Evaluation working paper WP-06-88. Chapel Hill, NC: Carolina Population Centre, University of North Carolina at Chapel Hill; 2006. Available at: http://www.cpc.unc. edu/measure/publications/wp-06-88/at_download/document. Accessed July 30, 2011.

13. Mberu BU. Protection before the harm: the case of condom use at the onset of premarital sexual relationship among youths in Nigeria. African Population Studies. 2008;22(2):58-83.

14. Fatusi AO, Blum RW. Predictors of early sexual initiation among a nationally representative sample of Nigerian adolescents. BMC Public Health. 2008;8:136.

15. Smith SD. "These girls na war-o": premarital sexuality and modern identity in southeastern Nigeria. Africa Today. 2000;47(3-4): 98-120.
16. Smith SD. Promiscuous girls, good wives and cheating husbands: gender inequality, transitions to marriage, and infidelity in southeastern Nigeria. Anthrop Q. 2010;83(1):123-152

17. Izugbara CO. Masculinity scripts and abstinence-related beliefs of rural Nigerian male youth. J Sex Res. 2008;45(3):262-276.

18. Izugbara CO. Representations of sexual abstinence among rural Nigerian adolescent males. Sex Res Social Policy. 2007;4(2):74-87.

19. Barker GK, Rich S. Influences on adolescent sexuality in Nigeria and Kenya: findings from recent focus-group discussions. Stud Fam Plann. 1992;23(3):199-210.

20. Temin MJ, Okonofua FE, Omorodion FO, et al. Perceptions of sexual behavior and knowledge about sexually transmitted diseases among adolescents in Benin City, Nigeria. Int Fam Plan Perspect. 1999;25(4):186-190.

21. Cornwall A. Spending power: love, money, and the reconfiguration of gender relations in Ada-Odo, southwestern Nigeria. Am Ethnol. 2002;29(4):963-980.

22. Erulkar AS, Bello M. The Experience of Married Adolescent Girls in Northern Nigeria. Abuja: The Population Council/AHIP; 2007. Available from: www.popcouncil.org/pdfs/Nigeria_MarriedAdol.pdf. Accessed July 30, 2011.

23. Folch-Lyon E, Trust JF. Conducting focus group sessions. Stud Fam Plann. 1981;12(12):443-449.

24. Shafritz LB, Roberts A. The value of focus-group research in targeting communication strategies: an immunization case study. Health Transit Rev. 1994;4(1):81-85.

25. Axelrod MD. 10 essentials for good qualitative research. Marketing News. 1975;8:10-11.

26. Burnard P. A method of analyzing interview transcripts in qualitative research. Nurse Educ Today. 1991;11(6):461-466.

27. Graneheim UH, Lundman B. Qualitative content analyis in nursing research: concepts, procedures and measures to acheive trustworthiness. Nurse Educ Today. 2004;24(2):105-112.

28. Kondracki NL, Wellman NS, Amundson DR. Content analysis: review of methods and their applications in nutrition education. J Nutr Educ Behav. 2002;34(4):224-230.

29. Karim AM, Magnani RJ, Morgan GT, Bond KC. Reproductive health risk and protective factors among unmarried youth in Ghana. Int Fam Plan Perspect. 2003:29(1):14-24.

30. Magnani RJ, Karim AM, Weiss LA, Bond KC, Lemba M, Morgan GT. Reproductive health risk and protective factors among youth in Lusaka, Zambia. J Adolesc Health. 2002;30(1):76-86.

31. Twa-Twa JM. The role of the environment in the sexual activity of school students in Tororo and Pallisa Districts of Uganda. Health Transit Rev. 1997;7 Suppl:67-81.

32. Orubuloye IO, Caldwell JC, Caldwell P. Diffusion and focus in sexual networking: identifying partners and partners' partners. Stud Fam Plann. 1992;23(6 Pt 1):343-351.

33. Ankomah A. Condom use in sexual exchange relationships among young single adults in Ghana. AIDS Edu Prev. 1998;10(4):303-316.

34. Gueye M, Castle S, Konaté K. Timing of first intercourse among Malian adolescents: implications for contraceptive use. Int Fam Plan Perspect. 2001;27(2):56-70.

35. Klepp KI, Ndeki SS, Thuen F, Leshabari M, Seha AM. Predicators of intention to be sexually active among Tanzanian school children. East Afr Med J. 1996;73(4):218-224.
Adolescent Health, Medicine and Therapeutics

\section{Publish your work in this journal}

Adolescent Health, Medicine and Therapeutics is an international, peer-reviewed, open access journal focusing on health, pathology, and treatment issues specific to the adolescent age group. All aspects of health maintenance, preventative measures and disease treatment interventions are addressed within the journal and practitioners from

\section{Dovepress}

all disciplines are invited to submit their work as well as healthcare researchers and patient support groups.. The manuscript management system is completely online and includes a very quick and fair peerreview system. Visit http://www.dovepress.com/testimonials.php to read real quotes from published authors. 